Semina $\square \quad \mathrm{Nr} 16$

Scientiarum 2017

s. $10-23$

DOI: http://dx.doi.org/10.15633/ss.2482

Andrzej Bielecki

\title{
Epistemologiczne problemy w biologii subkomórkowej: obserwacje, modele matematyczne i symulacje komputerowe
}

W naukach przyrodniczych pomiar i obserwacja maja znaczenie fundamentalne jako procedura weryfikująca teorię. Z drugiej strony ich wyniki sa zawsze interpretowane w ramach pewnej teorii. Występuje tu więc swoiste sprzężenie zwrotne ${ }^{1}$. Dodatkowo sprawę komplikuje fakt, że teoria jest konstruktem formalnym, często - zwłaszcza we współczesnej fizyce - matematycznym², natomiast pomiar i obserwacja realizowane sa w świecie przyrodniczym. Niezbędne są więc procedury pomostowe, łączące teorię, obejmująca modele zjawisk przyrodniczych i formalny aspekt procedur pomiarowych, ze światem zjawisk przyrodniczych i operacjonistycznym aspektem pomiaru jako takiego ${ }^{3}$.

Powyższe uwagi dotyczą sytuacji, gdy mamy pełne możliwości wykonania eksperymentu pomiarowego lub obserwacji. Jak widać, nawet w takim przypadku sytuacja jest złożona. Tym większe trud-

1 Zob. C. G. Hempel, Filozofia nauk przyrodniczych, tłum. B. Stanosz, Warszawa 2001, s. 33-37 oraz J. Życiński, Elementy filozofii nauki, Kraków 2015, s. 322-325.

2 Zob. R. Carnap, Logiczna struktura świata, tłum. P. Kawalec, Warszawa 2011, s. $9-10$.

3 Zob. R. Olejnik, Matematyczna teoria miary a metodologiczne analizy procedur pomiarowych, Tarnów 2011, s. 11-14, jak również M. Heller, Matematyczna a filozoficzna teoria miary, „Zagadnienia Filozoficzne w Nauce” 51 (2012), s. 152-154 oraz A. Bielecki, Mierzalne i niemierzalne, „Świat Nauki” 245 (2012), s. 82-83. 
ności występuja, gdy nie ma możliwości wykonania obserwacji lub eksperymentu pomiarowego lub są one istotnie ograniczone ze względu na sam charakter badanej rzeczywistości. Czynnikami ograniczającymi możliwości pomiarowe i obserwacyjne moga być: niedostępność bezpośrednia badanych obiektów (np. astrofizyka), skala czasowa badanych procesów (np. makroewolucja biologiczna), skala przestrzenna badanych procesów i struktur (np. badanie procesów wewnatrz komórki biologicznej) czy też sam charakter badanych zjawisk, które ze względu na oddziaływanie z aparaturą pomiarowa podlegają istotnym zmianom podczas pomiaru (np. zjawiska kwantowe). W wyspecyfikowanych przypadkach symulacja komputerowa, bazujacca na adekwatnym modelu matematycznym, może być pomocnym narzędziem rozszerzającym możliwości epistemologiczne.

\section{Związek teorii z empirią}

Związek teorii z empirią należy do podstawowych zagadnień filozofii nauki, a spory wokół niego mają w filozofii długa - bo zapoczątkowaną co najmniej w XIX wieku - i burzliwą historię. Pomijając szczegółową analizę wzajemnych relacji między teoria, na która składają się teorie naukowe, sformułowane na gruncie nauki prawa przyrody oraz modele, a empiria, rozumiana jako obserwacja, pomiar i metodologia eksperymentalna ${ }^{4}$, jak już wspomniano, między tymi dwoma podstawowymi aspektami nauk przyrodniczych występuje swoiste sprzężenie zwrotne, co widać na poniższym rysunku. Wpływ teorii na empirię symbolizuje strzałka oznaczona cyfra 1 . Teoria przewiduje nowe fakty ${ }^{5}$ i co za tym idzie - wyniki eksperymentu i obserwacji, co powoduje konieczność weryfikacji eksperymentalnej i pomiarowej. Teoria ukazuje również luki w dotychczasowej empirii - wskazuje, jakie eksperymenty należy wyko-

4 Dyskusję na temat tej problematyki można znaleźć w: M. Heller, Filozofia nauki. Wprowadzenie, Kraków 2011, s. 25-43.

5 Zob. I. Lakatos, Pisma z filozofii nauk empirycznych, tłum. W. Sady, Warszawa 1995 , s. $359-360$. 
nać (jeśli jeszcze nie zostały wykonane) albo jakich zjawisk szukać na gruncie obserwacji, aby odpowiedzieć na pytania, które w naturalny sposób wyłaniają się z danej teorii: „Oto pewna teoria utrzymywana dziśs przez uczonych.

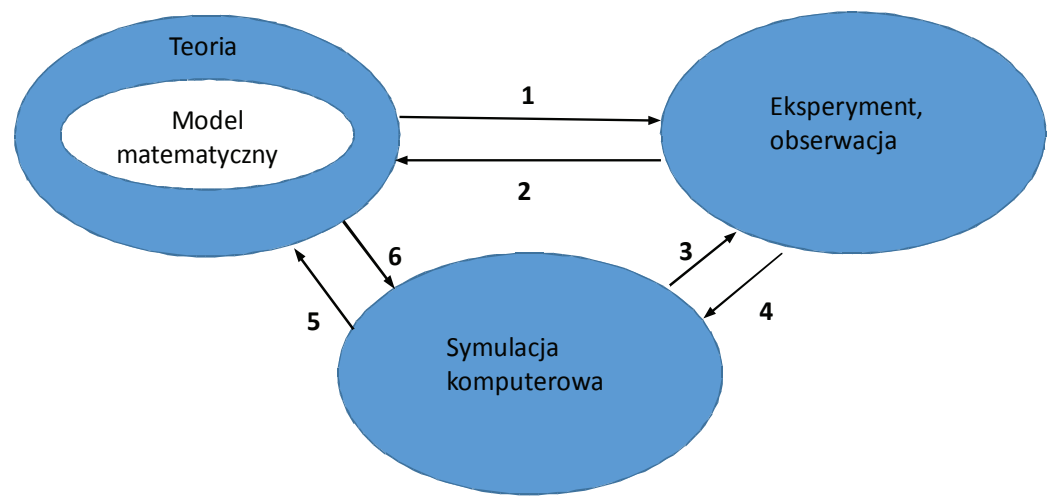

Rys. 1. Wzajemne zależności między teorią, eksperymentem i symulacją komputerowa.

Wynika z niej, że w określonych warunkach zaobserwować powinniśmy takie to a takie zjawiska. Sprawdźmy, czy tak jest rzeczywiście”. Stymuluje to generowanie nowych technik eksperymentalnych i obserwacyjnych. Wynik eksperymentu i obserwacji zawsze jest interpretowany $\mathrm{w}$ ramach pewnej teorii ${ }^{7}$. W wyspecyfikowanym wpływie teorii na empirię należy również brać pod uwagę, że teorii nigdy empirycznie nie da się w pełni potwierdzić, można ja jedynie empirycznie obalić ${ }^{8}$. Wpływ empirii na teorię symbolizuje na rysunku strzałka 2. Jeśli wynik eksperymentu lub obserwacji nie potwierdza teorii, to należy ją zmodyfikować lub uzupełnić, lub przeinterpretować, lub przeformułować, lub zastapić nowa. Ekspe-

6 K. R. Popper, Droga do wiedzy. Domysty i refutacje, tłum. S. Amsterdamski, Warszawa 1999, s. 221.

7 Zob. K. R. Popper, Logika odkrycia naukowego, tłum. U. Niklas, Warszawa 2002 , s. 53.

8 Zob. K. R. Popper, Wiedza obiektywna. Ewolucyjna teoria epistemologiczna, tłum. A. Chmielewski, Warszawa 2002, s. 313-314. 
ryment pozwala poznać charakter zjawiska i co za tym idzie - dobrać odpowiedni typ modelu.

Należy podkreślić, że zwłaszcza w biologii kierunek zależności między empirią a teorią dla konkretnego zagadnienia bywa przedmiotem sporów. Dla przykładu podajmy teorię ewolucji i paleontologię. Według jednych ekspertów zapis kopalny jest mocnym i niezaprzeczalnym dowodem prawdziwości teorii ewolucji we współczesnym ujęciu darwinowskim (tzw. teoria syntetyczna) ${ }^{9}$. Według innych:

Wbrew stereotypowemu przekonaniu, dokumentacja paleontologiczna nie może być użyta do uprawomocnienia teorii ewolucji Darwina. Rozumianej ściśle, jako teoria naukowa, a nie ideologia. Co najwyżej koncepcja ta jest pomocna przy interpretacji zapisu kopalnego ${ }^{10}$.

Jak wspomniano, relacja między teorią a empirią jest zagadnieniem klasycznym i choć subtelności związane z ich wzajemnymi relacjami nadal sa przez filozofów intensywnie dyskutowane, to problem od strony filozoficznej jest dobrze rozpoznany. W drugiej połowie XX wieku, dzięki rozwojowi techniki komputerowej, zarówno w aspekcie sprzętowym, jak i programistycznym w dyskutowanych problemach pojawiła się nowa jakość: możliwość symulacji komputerowych, w szczególności symulacji numerycznych. Pozwalają one, przy wszystkich ich ograniczeniach, uzyskać bardziej precyzyjny wgląd w procesy dynamiczne, m.in. w procesy biologiczne. Dzięki temu matematyczne modele dynamiczne oparte na równaniach różniczkowych, których nie jesteśmy w stanie rozwiązać analitycznie, czyli na nieliniowych równaniach różniczkowych zwyczajnych oraz na równaniach różniczkowych cząstkowych, zyskały istotnie nowy aspekt epistemologiczny dzięki możliwości numerycznego rozwiązywania tych równań. Symulacje komputerowe pozwalają również na precyzyjne modelowanie struktur bio-

9 Zob. D. J. Futuyma, Ewolucja, tłum. J. Radwan, Warszawa 2008, s. 67-71 oraz E. P. Solomon i in., Biologia, tłum. A. Borowska i in., Warszawa 2014, s. 397.

10 J. Dzik, Dzieje życia na Ziemi, Warszawa 2003, s. 8. 
logicznych jako struktur danych ${ }^{11}$ na podstawie wyników obrazowania w biologii ${ }^{12}$.

Punktem wyjścia symulacji komputerowej jest formalny model badanych procesów i struktur. Model zawsze jest uproszczony w stosunku do modelowanej rzeczywistości i jednym z głównych problemów jest wyodrębnienie tych wszystkich jej aspektów, które sa istotne $\mathrm{z}$ badawczego punktu widzenia. W celu dokonania komputerowych symulacji model musi być wysoce sformalizowany, najlepiej mieć charakter matematyczny. Między teoria, w szczególności matematycznym modelem, a narzędziami symulacji numerycznej również zachodzi swoiste sprzężenie zwrotne. Istotne jest przede wszystkim pytanie, na ile symulacja numeryczna jest adekwatna. W aspekcie symulacji układów dynamicznych, w tym procesów biologicznych modelowanych przy pomocy równań różniczkowych, adekwatność symulacji numerycznej oznacza, że układ dynamiczny generowany przez metodę numeryczną jest taki sam, jak generowany przez dyskretyzację czasową układu dynamicznego generowanego przez równanie różniczkowe, które modeluje rozważany proces.

Badanie powyższych aspektów doprowadziło do powstania i rozwoju arytmetyki przedziałowej, badania topologicznego sprzężenia kaskad oraz własności shadowing. Jest to przykład wpływu symulacji komputerowych na rozwój teorii będącej ich podstawa, co obrazuje strzałka 5 na rysunku. Poza tym jeśli model jest zależny od parametrów, które nie moga być oszacowane na gruncie teorii, symulacja komputerowa może pozwolić na ich oszacowanie. Z kolei teoria dostarcza narzędzi do oceny jakości symulacji numerycznej, np. stabilności procedury numerycznej czy też istnienia i jedyności rozwiązania użytego równania różniczkowego (strzałka 6). Można również przetestować różne modele - w przypadku procesów biologicznych np. probabilistyczne, oparte na równaniach różniczko-

11 Zob. A. Bielecki et al., Construction of a 3D Geometric Model of a Presynaptic Bouton for Use in Modeling of Neurotransmitter Flow, „Lecture Notes in Computer Science" 9972 (2016), s. 377-386.

12 Zob. B. G. Wilhelm et al., Composition of Isolated Synaptic Boutons Reveals the Amounts of Vesicle Trafficking Proteins, „Science” 344 (2014), s. 1023-1028. 
wych zwyczajnych i czastkowych - i sprawdzić, na ile ich przewidywania sa zgodne z eksperymentem. Powyższa procedura odpowiada przejściu od teorii do eksperymentu wzdłuż strzałki 6, a następnie 3. Sprzężenie zwrotne występuje również między eksperymentem a symulacjami (strzałki 3 i 4). Przy pomocy symulacji można zbadać, na ile warunki eksperymentu zaburzają badane zjawisko ${ }^{13}$. Symulacja komputerowa znajduje też zastosowanie m.in. w biochemii jako narzędzie do poznawania struktury i oddziaływań w białkach, kwasach nukleinowych i innych biomolekułach, w tym w badaniu szlaków biochemicznych w organizmach, co pozwala zredukować liczbę eksperymentów w kontekście badań biochemicznych (np. pakiet symulacyjny CHARMM) ${ }^{14}$. Z kolei np. brak możliwości wykonania eksperymentu w danych warunkach lub dla danych parametrów można uzupełnić symulacjami komputerowymi.

\section{Specyfika obserwacji w biologii subkomórkowej ze szczególnym uwzględnieniem neurofizjologii}

Dwiema zasadniczymi technikami obserwacyjnymi w biologii subkomórkowej jest mikroskopia elektronowa i mikroskopia optyczna. Mikroskopia elektronowa jednakże umożliwia wyłącznie badania in vitro. W związku z tym niezbędne jest odpowiednie przygotowanie materiału do badań. Tu wyłaniają się zasadnicze trudności metodologiczne, w sposób jawny wyspecyfikowane przez Harolda Hillmana (dyrektora Unity Laboratory of Applied Neurobiology, Guildford, Surrey w Wielkiej Brytanii) ${ }^{15}$. Przede wszystkim milczaco czynione są m.in. następujące założenia dotyczące etapu przygotowania próbki do badań:

13 Por. dyskusja w następnym rozdziale w kontekście biologii subkomórkowej.

14 Zob. B. R. Brooks et al., CHARMM: A Program for Macromolecular Energy, Minimization and Dynamics Calculations, „Journal of Computational Chemistry” 4 (1982), s. 187-217.

15 Zob. H. Hillman, Two Problems with Cell Biology and What Should Be Done about Them, „Biologist” 57 (2010) iss. 1, s. 40-44. 
a) homogenizacja i wirowanie materiału w wirówce nie ma wpływu na enzymy, w szczególności na ich aktywność chemiczną i lokalizację przestrzenną;

b) w próbce następuje równomierny rozkład energii przekazywanej w procesie przygotowywania próbki, np. w procesie wirowania;

c) zamrażanie próbki nie wpływa znacząco na badane struktury.

Hillman równocześnie podkreśla, że nie miały miejsca eksperymentalne weryfikacje pozwalające odpowiedzieć na następujące problemy związane z wyspecyfikowanymi powyżej założeniami:

a) Czy stosowane procedury nie zwiększają istotnie entropii próbki? (Zwiąek fizycznej strony procedur z druga zasadą termodynamiki).

b) Czy trzeba uwzględniać zmianę energii swobodnej?

c) Jaka ilość energii została dostarczona do próbki i czy zaburzyła w sposób istotny badane struktury i procesy?

Należy również podkreślić, że - jak wspomniano - przy pomocy mikroskopii elektronowej nie jest możliwe badanie żywych komórek i co za tym idzie - badanie procesów zachodzących w żywych komórkach. Najważniejszy aspekt biologiczny jest więc w tego typu badaniach nieobecny.

Mikroskopia optyczna pozwala na badanie in vivo. Ma to olbrzymie znaczenie w badaniu organizmów jednokomórkowych. W takim przypadku bowiem zwłaszcza organizmy żyjące w wodzie możemy umieścić pod mikroskopem w kropli wody, nie tracąc podczas badania nic lub tracąc niewiele ze specyfiki oddziaływania badanego organizmu z jego środowiskiem.

W neurofizjologii możliwości badania procesów zachodzących wewnątrz neuronu są ograniczone. Niewątpliwie jedną z przyczyn jest wspomniana skala tych procesów. Z drugiej strony być może mamy tu sytuację analogiczną do zjawisk kwantowych, w których sam pomiar istotnie zakłóca badany proces ${ }^{16}$. Z kolei neurony tworzą sieć nerwowa. Jeśli wyizolujemy do badań pojedynczy neuron, to tym samym poważnie zakłócimy badany obiekt, wyrywając go z jego natu-

${ }_{16}$ Zob. M. Knodel et al., Synaptic Bouton Properties Are Tuned to Best Fit the Prevailing Firing Pattern, „Frontiers in Computational Neuroscience” 8 (2014) art. 101, https://www.frontiersin.org/articles/10.3389/fncom.2014.00101/full (27.11.2017). 
ralnego środowiska i przerywając oddziaływania z innymi neuronami i komórkami glejowymi. Z kolei bezpośrednia obserwacja neuronów w organizmie jest ograniczona tylko do neuronów powierzchniowych. Ponadto w mikroskopii optycznej istnieje konieczność silnego oświetlenia badanego obiektu, co oznacza dostarczenie energii do układu. Dawka światła dostarczona do obiektu typu neuron nie jest dla tego obiektu obojętna. W takim wypadku pojawiają się na gruncie eksperymentu istotne trudności metodologiczne, zasygnalizowane wyżej. Stąd konieczność pośredniego wnioskowania na temat wartości pewnych istotnych parametrów charakteryzujących komórkę nerwową.

Zasygnalizowane problemy nie pozwalają do końca zgodzić się z teza, że współczesna biologia „nie może narzekać na kryzys procesu poznawczego" ${ }^{17}$. Modelowanie procesów wewnątrzkomórkowych w neuronie przy pomocy algorytmów bazujaccych na równaniach różniczkowych cząstkowych pozwala na uchwycenie zarówno przestrzennego, jak też dynamicznego (czasowego) aspektu modelowanego procesu ${ }^{18}$. Takie podejście pozwoliło m.in. na oszacowanie rzędu wielkości współczynnika dyfuzji neurotransmiterów w kolbce presynaptycznej $^{19}$.

\section{Specyfika modelowania matematycznego i symulacji komputerowych w biologii subkomórkowej ze szczególnym uwzględnieniem neurofizjologii}

W niniejszym rozdziale dyskutowana jest - od strony epistemologicznej - specyfika używanych powszechnie technik modelowania matematycznego i symulacji komputerowych w biologii subkomórkowej. Następnie omawiamy perspektywy rozwoju nowych technik.

17 P. Lenartowicz, Elementy filozofii zjawiska biologicznego, Kraków 1984, s. 17.

18 Zob. A. Bielecki, P. Kalita, Model of Neurotransmitter Fast Transport in Axon Terminal of a Presynaptic Neuron, „Journal of Mathematical Biology” 56 (2008), s. 559-576 oraz A. Bielecki et al., Numerical Simulation for a Neurotransmitter Transport Model in the Axon Terminal of a Presynaptic Neuron, „Biological Cybernetics" 102 (2010), s. 489-502.

19 Zob. A. Bielecki et al., Numerical Simulation..., dz. cyt. 
Jak już wspomniano w rozdziale drugim, równania różniczkowe - zarówno zwyczajne, jak i cząstkowe - a także modele probabilistyczne sa szeroko używane do modelowania procesów subkomórkowych. Analogicznie do problemów sygnalizowanych przez Hillmana dla technik obserwacyjnych można wyspecyfikować następujące przykładowe problemy, które należy starannie rozważyć przy stosowaniu modeli matematycznych i symulacji komputerowych do opisu procesów biologicznych:

a) fragmentaryczność użytego modelu, w szczególności problem wyboru skali;

b) adekwatność użytego modelu, np. przybliżanie procesów dyskretnych przez modele ciagle;

c) własności modelu matematycznego;

d) dyskretyzacja modeli ciagłych;

e) problem zachowywania własności modelu matematycznego przy przejściu do symulacji numerycznych;

f) własności symulacji numerycznych, np. zgodność, zbieżność i stabilność schematu różnicowego użytego do numerycznej symulacji cząstkowego równania różniczkowego;

g) problem miary jakości siatki wygenerowanej na potrzeby numerycznej symulacji równania różniczkowego;

h) problem warunku początkowego.

Przedyskutujmy powyższe problemy w kontekście równań różniczkowych jako powszechnie używanego narzędzia modelowania procesów. Dany model, w szczególności matematyczny, opisuje jedynie fragment badanego zjawiska. Istotne jest więc sprecyzowanie, jaki fragment powinien być wyspecyfikowany jako punkt wyjścia do zbudowania modelu i jaka skala zjawiska jest dla badacza interesująca w świetle postawionego problemu badawczego. Przykładowo w modelowaniu procesów szybkiego transportu neurotransmiterów ${ }^{20}$ i wolnego transportu neuropeptydów ${ }^{21} \mathrm{w}$ kolbce presynaptycznej interesuje nas transport pęcherzyków wypełnionych neuromediatora-

20 Zob. A. Bielecki, P. Kalita, Model of Neurotransmitter..., dz. cyt.

21 Zob. A. Bielecki et al., Compartment Model of Neuropeptide Synaptic Transport with Impulse Control, „Biological Cybernetics” 99 (2008), s. 443-458. 
mi i ich aktywacja przy pomocy jonów wapniowych. Oznacza to, że rozpatrujemy zjawisko w skali organelli komórkowych, np. mitochondrium $^{22}$, a nie schodzimy do poziomu np. enzymów.

Problem fragmentaryczności i skali wiąże się bezpośrednio z adekwatnością modelu, który kreujemy w konkretnym celu. Pytanie, czy model wykreowany dla danego fragmentu rzeczywistości i danej skali jest wystarczający w kontekście danego problemu badawczego, jest istotny z perspektywy epistemologicznej. Jako przykład można zadać pytanie, czy adekwatne jest użycie ciagłego modelu różniczkowego do modelowania transportu neuromediatorów, skoro w kolbce presynaptycznej ten transport odbywa się przy użyciu pęcherzyków wypełnionych mediatorem, a nie w formie przepływu substancji, jest więc z natury swojej dyskretny, a nie ciagły. Model matematyczny ma pewne własności, które determinują jego przydatność w kontekście modelowania. Przykładowo model różniczkowy jest użyteczny, gdy posiada rozwiązanie, które dodatkowo jest jednoznaczne, ograniczone oraz dostatecznie regularne, tzn. m.in. zależne w sposób ciagły od danych oraz mające pochodne odpowiedniego rzędu.

Najczęściej na gruncie użytego modelu matematycznego nie potrafimy bezpośrednio otrzymać rozwiązań, które musimy wtedy generować przy użyciu procedur numerycznych. Przejście do modelu numerycznego również posiada epistemologiczną specyfikę. Pierwszym problemem jest wybranie odpowiedniego schematu numerycznego. Dla danego problemu ciagłego schematów takich jest teoretycznie nieskończenie wiele. Każdy ma swoją specyfikę, a praktyczny problem symulacji, mający istotny aspekt epistemologiczny, to osiagnięcie kompromisu między dokładnością symulacji a złożonością obliczeniowa. Jak już wspomniano w rozdziale 2 , z problemem dyskretyzacji wiążą się głębokie problemy matematyczne związane z zachowywaniem własności dynamicznych modelu ciagłego przez schemat różnicowy oraz z niedokładnością symulacji, spowodowaną błędami zaokragleń w arytmetyce realizowanej na komputerze. Użyty schemat numeryczny, podobnie jak wyjściowy model matematyczny, też ma pewne własności matematyczne określające jego przydatność. Naj-

${ }^{22}$ Zob. A. Bielecki et al., Construction of a $3 D$ Geometric Model..., dz. cyt. 
ogólniej rzecz ujmując, schemat numeryczny musi mieć odpowiednie własności manifestujące się jego zachowaniem przy zmniejszaniu kroku przestrzennego i czasowego, jak też przy przejściach granicznych, np. w granicy nieskończonego czasu. W dyskretyzacji problemu opisywanego czastkowymi równaniami różniczkowymi istotna kwestia jest generacja siatki, w której węzłach będą realizowane obliczenia różnicowe. Siatka taka powinna mieć ściśle określone własności, w szczególności jej oczka powinny być mniejsze w obszarach, w których dynamika jest bardziej zmienna. Wyselekcjonowanie takich obszarów bez wykonania obliczeń jest trudne, a wykonanie obliczeń wymaga odpowiedniej siatki, co rodzi problem błędnego koła. Specyficznym dla równań różniczkowych problemem jest określenie warunku początkowego. Jest to w procesach biologicznych bardzo subtelny problem, gdyż trudno w nich wyodrębnić jakikolwiek naturalny początek, co powoduje, że warunek początkowy zawsze jest w pewnym sensie sztuczny jako niebiologiczny.

Niektóre z wymienionych problemów są częściowo rozpracowane teoretycznie w formie odpowiednich twierdzeń matematycznych. Wiadomo na przykład, że dla czastkowych równań różniczkowych zgodność i stabilność implikuje zbieżność oraz że równania liniowe i gradientowe mają własność shadowing. Problematyka badania istnienia i jednoznaczności rozwiązań równania różniczkowego jest we współczesnej matematyce intensywnie badana. Niemniej jednak wiele zasygnalizowanych problemów na poziomie matematycznym pozostaje otwartych, a dyskutowana problematyka nie jest dostatecznie przeanalizowana w kontekście filozofii informatyki oraz epistemologii nauk przyrodniczych. Należy przy tym jeszcze raz podkreślić, że w niniejszym artykule ograniczyliśmy się jedynie do analizy problemu w kontekście równań różniczkowych, pomijając np. modele probabilistyczne.

\section{Uwagi końcowe}

Jak wspomniano we wstępie niniejszego artykułu, relacje między teorią a empirią w naukach przyrodniczych od dłuższego czasu były intensywnie poddawane refleksji filozoficznej. Z drugiej strony w cią- 
gu ostatnich kilkudziesięciu lat symulacje komputerowe wyłoniły się jako nowa jakość epistemologiczna w naukach przyrodniczych. Specyfika tego stosunkowo nowego - zwłaszcza na gruncie nauk biologicznych - narzędzia nie doczekała się, jak dotąd, pogłębionych badań epistemologicznych. Niniejszy artykuł miał na celu zasygnalizowanie pewnych problemów związanych z tą tematyką i ewentualnie wskazanie kierunku dalszych badań.

Podsumowujac, symulacja komputerowa bazująca na modelach matematycznych (nie tylko na bazie równań różniczkowych) jest komplementarnym - w stosunku do klasycznych (obserwacja, eksperyment) - narzędziem epistemologicznym wchodzącym w złożone relacje metodologiczne z narzędziami klasycznymi. Pozwala na wyciąganie wniosków w sytuacjach, gdy nie jest możliwa obserwacja lub eksperyment, w szczególności na oszacowanie niemierzalnych (na obecnym etapie rozwoju technik eksperymentalnych) parametrów. Pozwala również na eksperymentowanie z modelami zarówno w aspekcie teoretycznym, jak też symulacyjnym. Generuje nowe problemy filozoficzne, np. pytanie, na ile biologia jest matematyczna - dotychczas matematyczność świata była rozpatrywana głównie w kontekście fizyki.

\section{Summary}

\section{Epistemological problems in subcellular biology: observations, mathematical models and computer simulations}

Relations between theory and empirical knowledge belong to basic problems in philosophy of science and have been undergone detailed philosophical reflection, including epistemological aspects. During last several dozen years, due to development of computer technology, numerical simulations became a common tool in natural sciences. Their epistemological aspects, however, have not worked out yet. A specific role of computer simulations manifests in subcellular biology, where possibilities of performing experiments and observations are limited. Computer simulation is complementary to observation and experiment and comes into complex relations with them. It allows us to come to a conclusion if experiment or observations are impossible to perform. In particular, simulations allow researchers to estimate the parameters that cannot be measured. 
Keywords: experiment, observation, theory, model, numerical simulations, subcellular biology

\section{Bibliografia}

Bielecki A., Gierdziewicz M., Kalita P., Szostek K., Construction of a 3D Geometric Model of a Presynaptic Bouton for Use in Modeling of Neurotransmitter Flow, „Lecture Notes in Computer Science” 9972 (2016), s. 377-386.

Bielecki A., Kalita P., Lewandowski M., Siwek B., Numerical Simulation for a Neurotransmitter Transport Model in the Axon Terminal of a Presynaptic Neuron, „Biological Cybernetics” 102 (2010), s. 489-502.

Bielecki A., Kalita P., Lewandowski M., Skomorowski M., Compartment Model of Neuropeptide Synaptic Transport with Impulse Control, „Biological Cybernetics" 99 (2008), s. 443-458.

Bielecki A., Kalita P., Model of Neurotransmitter Fast Transport in Axon Terminal of a Presynaptic Neuron, „Journal of Mathematical Biology” 56 (2008), s. 559-576.

Bielecki A., Mierzalne i niemierzalne, „Świat Nauki” 245 (2012), s. 82-83.

Brooks B. R., Bruccoleri R. E., Olafson B. D., States D. J., Swaminathan S., Karplus M., CHARMM: A Program for Macromolecular Energy, Minimization and Dynamics Calculations, „Journal of Computational Chemistry” 4 (1982), s. 187-217.

Carnap R., Logiczna struktura świata, tłum. P. Kawalec, Warszawa 2011.

Dzik J., Dzieje życia na Ziemi, Warszawa 2003.

Futuyma D. J., Ewolucja, tłum. J. Radwan, Warszawa 2008.

Heller M., Filozofia nauki. Wprowadzenie, Kraków 2011.

Heller M., Matematyczna a filozoficzna teoria miary, „Zagadnienia Filozoficzne w Nauce" 51 (2012), s. 152-154.

Hempel C. G., Filozofia nauk przyrodniczych, tłum. B. Stanosz, Warszawa 2001.

Hillman H., Two Problems with Cell Biology and What Should Be Done about Them, „Biologist” 57 (2010) iss. 1, s. 40-44.

Knodel M., Geiger R., Ge L., Bucher D., Grillo A., Wittum G., Schuster C., Queisser G., Synaptic Bouton Properties Are Tuned to Best Fit the Prevailing Firing Pattern, „Frontiers in Computational Neuroscience” 8 (2014) 
art. 101, https:/www.frontiersin.org/articles/10.3389/fncom.2014.00101/ full (27.11.2017).

Lakatos I., Pisma z filozofii nauk empirycznych, tłum. W. Sady, Warszawa 1995.

Lenartowicz P., Elementy filozofii zjawiska biologicznego, Kraków 1984.

Olejnik R., Matematyczna teoria miary a metodologiczne analizy procedur pomiarowych, Tarnów 2011.

Popper K. R., Droga do wiedzy. Domysty i refutacje, tłum. S. Amsterdamski, Warszawa 1999.

Popper K. R., Logika odkrycia naukowego, tłum. U. Niklas, Warszawa 2002.

Popper K. R., Wiedza obiektywna. Ewolucyjna teoria epistemologiczna, tłum. A. Chmielewski, Warszawa 2002.

Solomon E. P., Berg L. R., Martin D. W., Biologia, tłum. A. Borowska i in., Warszawa 2014.

Wilhelm B. G., Mandad S., Truckenbrodt S., Krohnert K., Schafer C., Rammner B., Seong J. K., Gala A. C., Krauss M., Haucke V., Urlaub H., Rizzoli S. O., Composition of Isolated Synaptic Boutons Reveals the Amounts of Vesicle Trafficking Proteins, „Science” 344 (2014), s. 1023-1028.

Życiński J., Elementy filozofii nauki, Kraków 2015. 